University of Nebraska - Lincoln

DigitalCommons@University of Nebraska - Lincoln

Court Review: The Journal of the American

Judges Association

American Judges Association

2017

From Playgrounds to Plavix: Civil Cases in the Supreme Court's

October 2016 Term

Todd E. Pettys

University of lowa College of Law

Follow this and additional works at: https://digitalcommons.unl.edu/ajacourtreview

Pettys, Todd E., "From Playgrounds to Plavix: Civil Cases in the Supreme Court's October 2016 Term"

(2017). Court Review: The Journal of the American Judges Association. 607.

https://digitalcommons.unl.edu/ajacourtreview/607

This Article is brought to you for free and open access by the American Judges Association at DigitalCommons@University of Nebraska - Lincoln. It has been accepted for inclusion in Court Review: The Journal of the American Judges Association by an authorized administrator of DigitalCommons@University of Nebraska -

Lincoln. 


\title{
From Playgrounds to Plavix: Civil Cases in the Supreme Court's October 2016 Term
}

\author{
Todd E. Pettys
}

D uring the Supreme Court's October 2016 Term, news relating to Donald Trump's rise to the presidencyincluding his successful nomination of Neil Gorsuch to fill the vacancy created by Justice Antonin Scalia's death more than one politically eventful year earlier-frequently overshadowed news of the Court's rulings. The Court itself contributed to that redirection of the nation's attention: it decided more than 30 fewer cases than its recent average, and it achieved unanimity at an unusually high rate. ${ }^{1}$ With $68 \%$ of the Court's rulings falling on the civil side of the ledger, ${ }^{2}$ however, we have much here to discuss, with significant new rulings in the areas of arbitration, debt collection, disabilities and education, discovery sanctions, equal protection, fair housing, false claims, family law and veterans benefits, jurisdiction, patents, religion, sovereign immunity, speech, takings, and the Trump Administration's "travel ban."

\section{ARBITRATION}

The Supreme Court's long-running campaign to bring state courts into compliance with the Federal Arbitration Act continued this past Term with its ruling in Kindred Nursing Centers Limited Partnership v. Clark. ${ }^{3}$ Exercising their respective powers of attorney, Janis Clark and Beverly Wellner had completed the paperwork necessary to move family members into a Kentucky nursing home. The contracts with the nursing home stated that all controversies concerning the family members' stay at the facility would be resolved through binding arbitration, rather than through litigation. When the family members died not long thereafter, Clark and Wellner brought suits against the nursing home on behalf of the decedents' estates. Were those suits contractually barred? The Kentucky Supreme Court held they were not. A power of attorney does not empower a representative to enter into an arbitration agreement, Kentucky's high court reasoned, unless it contains a statement explicitly conferring that authority. Otherwise, the Kentucky justices said, agents could waive their principals' core constitutional rights of access to the courts and trial by jury.

Led by Justice Kagan, the Court unanimously reversed. In a prior ruling concerning the FAA's requirements, the Court had explained that "courts must place arbitration agreements on an equal footing with other contracts" and that arbitration agreements thus cannot be invalidated "by defenses that apply only to arbitration or that derive their meaning from the fact that an agreement to arbitrate is at issue." Justice Kagan explained that the Kentucky Supreme Court had violated these principles when it held that, absent a clear statement to the contrary, a power-of-attorney contract cannot confer the power to waive a principal's right to sue or to invoke his or her right to a jury trial. "Such a rule is too tailor-made to arbitration agreementssubjecting them, by virtue of their defining trait, to uncommon barriers-" Justice Kagan wrote, "to survive the FAA's edict against singling out those contracts for disfavored treatment."5

\section{DEBT COLLECTION}

The Court handed down two significant rulings this Term on the Fair Debt Collection Practices Act. In his first opinion for the Court, Justice Neil Gorsuch led his colleagues in unanimously rejecting a claim brought by debtors who believed that their rights under the Act had been violated. The case, Henson v. Santander Consumer USA, Inc. ${ }^{6}$ featured a debt collectorSantander - that had purchased defaulted auto loans from CitiFinancial Auto and then deployed collection methods that the debtors found legally objectionable. The Act places methodological restraints upon (among others) anyone "who regularly collects or attempts to collect . . . debts owed or due another."7 The parties agreed that the statute applies to agents who attempt to collect debts on behalf of creditors, and they also agreed that the statute does not ordinarily apply to those who attempt to collect debts that they themselves originated. But what about someone who-like Santander-purchases debts originated by others and then seeks to recover on those debts for its own financial benefit?

"[B]y its plain terms," Justice Gorsuch wrote, the statutory language at issue brings within the Act's scope "third party collection agents working for a debt owner-not . . . a debt owner seeking to collect debts for itself." ${ }^{\circ}$ This is true, Justice Gorsuch said, regardless of whether the debt owner "originated the debt or came by it only through a later purchase." As for the debtors' argument that Congress would have wished to bring the Act to bear on debt purchasers if it had known that this "new industry would blossom," Justice Gorsuch stressed that "it is never our job to rewrite a constitutionally valid statutory text under the banner of speculation about what Congress might have done had it faced a question that, on everyone's account, it never faced." 9

Suppose a debt collector asserts a right to be paid on a credit-card debt and that, on the face of the claim, it is clear

\section{Footnotes}

1. Kedar S. Bhatia, Stat Pack for October Term 2016, SCOTUSBLog, 8 , 16 (June 28, 2017), http://scotusblog.com/wp-content/ uploads/2017/06/SB_Stat_Pack_2017.06.28.pdf.

2. See id. at 6 .

3. 137 S. Ct. 1421 (2017).
4. AT\&T Mobility LLC v. Concepcion, 563 U.S. 333, 339 (2011).

5. Kindred Nursing Centers, 137 S. Ct. at 1427.

6. 137 S. Ct. 1718 (2017)

7. 15 U.S.C. \& $1692 \mathrm{a}(6)$.

8. Henson, 137 S. Ct. at 1721.

9. Id. at 1725 . 
that the statute of limitations for collecting the debt has expired. Does the assertion of the claim amount to a "false, deceptive, or misleading representation" or an "unfair or unconscionable means" of attempting to collect a debt, in violation of the Act? ${ }^{10}$ In Midland Funding, LLC v. Johnson, ${ }^{11}$ the Court held that such a claim does not violate the federal statute when the claim is asserted in Chapter 13 bankruptcy proceedings. In that context, Justice Breyer reasoned for the majority, there are a variety of protections that help to ensure that the patently stale claim will be rejected. The Court reserved judgment, however, on whether the Act bars "a debt collector's assertion in a civil suit of a claim known to be stale"- a setting in which a consumer might easily be duped into paying a timebarred debt in order to avoid litigation. ${ }^{12}$ Joined by Justices Ginsburg and Kagan, Justice Sotomayor dissented, arguing that a debt collector violates the Act when it attempts to collect a debt that it knows is time-barred. Faced with a contrary ruling by a majority of their colleagues, the dissenting justices urged Congress to amend the legislation.

\section{DISABILITIES AND EDUCATION}

Through a variety of federal statutes, Congress has aimed to protect the interests of children with disabilities. Prominent among those statutes are the Individuals with Disabilities Education Act, Title II of the Americans with Disabilities Act, and Section 504 of the Rehabilitation Act. A provision of the IDEA-20 U.S.C. \& 1415(1)—states that, even if suing under a statute other than the IDEA, a disabled child must first exhaust the IDEA's administrative procedures if he or she is "seeking relief that is also available under [the IDEA]." The Court was asked to interpret the meaning of that exhaustion provision in Fry v. Napoleon Community Schools. ${ }^{13}$ A child with cerebral palsy had sued a school after it refused to allow her to bring her service dog on the premises. The child sued under Title II of the ADA and Section 504 of the Rehabilitation Act, but did not first exhaust the IDEA's administrative procedures. Was the failure to exhaust a problem?

Pointing out that the IDEA's "principal command" is that disabled children be provided with what the statute describes as "a free appropriate public education" (commonly called a FAPE), ${ }^{14}$ Justice Kagan explained in her opinion for the Court that the IDEA's exhaustion requirements only apply when "the gravamen" of the plaintiff's complaint concerns a school's alleged failure to provide a FAPE. ${ }^{15}$ To help lower courts determine whether a given complaint fits that description, Justice Kagan offered a couple of diagnostic questions:

First, could the plaintiff have brought essentially the same claim if the alleged conduct had occurred at a public facility that was not a school—say, a public theater or library? And second, could an adult at the school-say, an employee or visitor-have pressed essentially the same grievance? When the answer to those questions is yes, a complaint that does not expressly allege the denial of a FAPE is also unlikely to be truly about that subject [and so the IDEA's exhaustion requirements will not apply].16

The Court remanded for an application of those principles. Joined by Justice Thomas in a short opinion concurring in part and concurring in the judgment, Justice Alito worried that the majority's two diagnostic questions would confuse the lower courts. Those questions, Justice Alito wrote, evidently presume that "there is no overlap between the relief available under" the IDEA, on the one hand, and the relief available under the ADA, the Rehabilitation Act, or some other federal law, on the other. ${ }^{17}$

During his Senate confirmation hearings for a seat on the Court, then-Judge Gorsuch took some heat from critics $^{18}$ for authoring a Tenth Circuit opinion stating that, to satisfy the FAPE requirements of the IDEA, the educational benefits being provided to a disabled student by a school "must merely be "more than de minimis."'19 That criticism was not altogether fair; as the internal quotation marks in the prior sentence indicate, Gorsuch was invoking the standard previously adopted by the Tenth Circuit, although it also is true that he added the word "merely" to the formulation. With or without that adverbial modifier, the Tenth Circuit's standard is no longer good law.

In Endrew F. v. Douglas County School District RE-120—a case concerning a Tenth Circuit ruling in which Gorsuch did not participate, but in which his framing of the Tenth Circuit's standard had been deployed-the Court unanimously held that the Tenth Circuit had failed to interpret the IDEA and the Court's own precedent appropriately. Writing for the Court, Chief Justice Roberts explained that, to satisfy the IDEA's mandate, "a school must offer an [individualized education program, or 'IEP'] reasonably calculated to enable a child to make progress appropriate in light of the child's circumstances."21 Although an IEP need not be "ideal," Chief Justice Roberts wrote, it "must aim to enable the child to make progress" and thus must be "constructed only after careful consideration of
10. 15 U.S.C. $\S \S 1692 \mathrm{e}, 1692 \mathrm{f}$

11. 137 S. Ct. 1407 (2017).

12. Id. at 1413.

13. 137 S. Ct. 743 (2017).

14. 20 U.S.C. $\S \S 1400(d)(1)(A), 1415(a)$.

15. Fry, 137 S. Ct. at 752-57.

16. Id. at 756 .

17. Id. at 759 (Alito, J., concurring in part and concurring in the judgment).
18. See Mark Walsh, Debate on Gorsuch and Special Education Rulings Continues on Last Day of Hearing, EduCATION WeEk (Mar. 23, 2017, 6:05 PM), http://blogs.edweek.org/edweek/school_law/ 2017/03/debate_on_gorsuch_and_idea_rul.html.

19. Thompson R2-J Sch. Dist. v. Luke P., 540 F.3d 1143, 1149 (10th Cir. 2008) (quoting Urban ex rel. Urban v. Jefferson County Sch. Dist. R-1, 89 F.3d 720, 727 (10th Cir. 1996)).

20. 137 S. Ct. 988 (2017).

21. Id. at 999. 


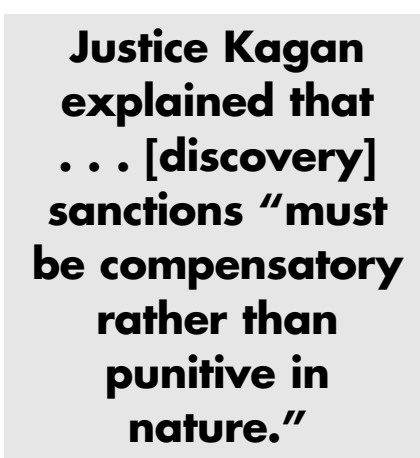

the child's present levels of achievement, disability, and potential for growth."22 By requiring that a disabled child's educational program be "appropriately ambitious in light of his circumstances," the IDEA imposes a requirement that "is markedly more demanding than the 'merely more than de minimis' test applied by the Tenth Circuit."23

\section{DISCOVERY SANCTIONS}

Imagine you are a federal judge presiding over a tort lawsuit in which the plaintiffs allege that a defective tire manufactured by the defendant caused their motorhome to crash. After several years of discovery, the parties settle. Months later, the plaintiffs learn that-despite discovery requests that were squarely on point - the defendant had concealed internal test results indicating that the tire grew unusually hot at highways speeds. The plaintiffs return to your courtroom, urging you to order the defendant to pay all of the attorney's fees and other litigation costs that the plaintiffs incurred after the defendant's first refusal to disclose the test results. Does your inherent power to impose sanctions for litigation misconduct extend that far?

That was the question before the Court in Goodyear Tire \& Rubber Co. v. Haeger. ${ }^{24}$ The district court in that case had awarded the plaintiffs $\$ 2.7$ million, covering all of the fees and costs that the plaintiffs had paid after Goodyear's first dishonest response to a discovery request concerning Goodyear's internal tests on the G159 tire model. The Ninth Circuit affirmed, but the Supreme Court unanimously reversed. Drawing heavily from the Court's 1994 ruling in Mine Workers $v$. Bagwell, 25 Justice Kagan explained that-regardless of whether a court is imposing sanctions pursuant to a rule of civil procedure, 28 U.S.C.\$ 1927, or the court's inherent sanctioning authority-sanctions "must be compensatory rather than punitive in nature." 26 "[P] retty much by definition," Justice Kagan wrote, that means that a "court can shift only those attorney's fees incurred because of the misconduct at issue." 27 When making that causal assessment, a district court has considerable discretion. If presented with an "exceptional" case, for example, the but-for standard "permits a trial court to shift all of a party's fees, from either the start or some midpoint of a suit, in one fell swoop." 28 In this particular case, however, the record did not support a finding "that disclosure of the heattest results would have led straightaway to a settlement." 29 Notwithstanding the internal test results, Goodyear still could have argued that the plaintiff's tire failed for reasons attributable to the plaintiffs themselves (such as failing to replace it after it had worn down), and, in a separate lawsuit concerning a G159 tire, Goodyear had disclosed the test results and nevertheless proceeded to trial. The court thus remanded for application of the proper analysis.

\section{EQUAL PROTECTION}

\section{Immigration}

For more than half a century, the nation's immigration laws treated unwed U.S. citizen mothers significantly more favorably than it treated (and still treats today) unwed U.S. citizen fathers in determining the citizenship of children born abroad. For such a father to transfer American citizenship to his child, he must have resided in the United States for five or more years before the child's birth, and at least two of those years must come after the father reaches the age of fourteen. For a child born abroad to a U.S. citizen father before November 14, 1986, the requirement is even more demanding: the father must have resided in the United States for ten or more years prior to the child's birth, with at least five of those years coming after the father reached the age of fourteen. If a child was born abroad to an unwed U.S. citizen mother, however-whether before or after 1986-the statutory requirement was far more lenient: the child became an American citizen so long as the mother had resided in the United States for at least one year prior to the child's birth.

The Court declared that arrangement unconstitutional in Sessions v. Morales-Santana, ${ }^{30}$ though the news for the claimant in that case was nevertheless ultimately unfavorable. Luis Ramón Morales-Santana was born in the Dominican Republic in 1962 to unwed parents. Morales-Santana's father-but not his mother-was an American citizen. Yet Morales-Santana's father had fallen twenty days short of meeting the lengthy, statutorily imposed residence requirement for obtaining American citizenship for his son. Later facing deportation as a result of criminal convictions, Morales-Santana challenged the statute's differing treatment of unwed mothers and fathers, contending that it violated the Fifth Amendment's equal protection principles.

Led by Justice Ginsburg, a majority of the Court agreed. ${ }^{31}$ Applying intermediate scrutiny, the Court found that the statute's distinction between mothers and fathers lacked the necessary "exceedingly persuasive justification." 32 The Court concluded that the distinction-first drawn in the mid-twentieth century-was the result of an anachronistic assumption that mothers are children's primary guardians and that fathers commonly play little or no role in shaping children's values and civic attachments:
22. Id.

23. Id. at 1000.

24. 137 S. Ct. 1178 (2017).

25. 512 U.S. 821 (1994).

26. Goodyear Tire E Rubber, 137 S. Ct. at 1186.

27. Id. (emphasis added).

28. Id. at 1187 (emphasis added).
29. Id at 1189 .

30. 137 S. Ct. 1678 (2017).

31. Before reaching the merits of the equal-protection claim, the Court found that Morales-Santana was entitled to assert the equalprotection rights of his deceased father.

32. Id. at 1690 (internal quotation omitted). 
Fearing that a foreign-born child could turn out more alien than American in character, the [Franklin Delano Roosevelt] administration believed that a citizen parent with lengthy ties to the United States would counteract the influence of the alien parent. Concern about the attachment of foreign-born children to the United States explains the treatment of unwed citizen fathers, who, according to the familiar stereotype, would care little about, and have scant contact with, their nonmarital children. For unwed citizen mothers, however, there was no need for a prolonged residency prophylactic: The alien father, who might transmit foreign ways, was presumptively out of the picture. ${ }^{33}$

The Court's ruling on the merits of Morales-Santana's claim left the justices with a choice: should they extend the benefits of the one-year residence requirement to children born abroad to unwed U.S. citizen fathers (as Morales-Santana desired), or should they instead declare that children born abroad to unwed U.S. citizen mothers become American citizens only if their mothers meet the lengthier residence requirement previously imposed only on fathers? The Court chose the latter option. The decision hinged, Justice Ginsburg explained, on what Congress would have desired if it had known that its mother-father distinction would be struck down as unconstitutional. The Court found that "all indicators" suggest Congress would have wished to retain the lengthier residence requirement. ${ }^{34}$ Morales-Santana himself thus failed to benefit from the Court's ruling. ${ }^{35}$

\section{Legislative Redistricting}

The Court handed down several important rulings this Term concerning the Equal Protection Clause and legislative redistricting. First up was Bethune-Hill v. Virginia Board of Elections, ${ }^{36}$ in which the Court clarified a portion of the analysis that applies when determining whether a state permissibly took race into account when drawing the boundaries of its legislative districts. Virginia conceded that, when setting the boundaries of eleven of its districts in the wake of the 2010 census, one of its goals was to ensure that each of those districts would have a black voting-age population of at least $55 \%$. Such action will draw strict scrutiny if race was the predominant factor that the state used when placing voters inside or outside the challenged districts. Was it? The lower court held that race was not the predominant factor because the eleven districts' boundaries could have been drawn in precisely the same way using traditional, constitutionally permissible criteria.

Led by Justice Kennedy, the 6-2 Court reversed and remanded. "The racial predominance inquiry concerns the actual considerations that provided the essential basis for the lines drawn," Justice Kennedy explained, "not post hoc justifications the legislature in theory could have used but in reality did not." 37 Of course, when the placement of districts' lines does conflict with traditional criteria, it might be quite easy for a challenger to establish an equal-protection claim. But "a conflict or inconsistency between the

The Court handed
down several
important rulings
this Term
concerning the
Equal Protection
Clause and
legislative
redistricting.
enacted plan and traditional redistricting criteria is not a threshold requirement or a mandatory precondition in order for a challenger to establish a claim of racial gerrymandering." 38 Rather than find that race did predominate here and that strict scrutiny was thus appropriate, the Court remanded for an application of the proper legal analysis. Given the state's admission that it tried to ensure a black voting-age population of at least 55\%, Justices Alito and Thomas would have held that race did indeed predominate and that strict scrutiny should apply. 39

The second of the Court's redistricting cases this Term was Cooper v. Harris ${ }^{40}$ a case concerning North Carolina's District 1 and District 12. Neither of those districts had a majority black voting-age population before redistricting, but both of them routinely elected candidates favored by a majority of black voters. The state added a substantial number of AfricanAmerican voters to both districts, pushing their black votingage populations beyond $50 \%$. In an effort to rebut allegations of unconstitutional racial gerrymandering, North Carolina officials argued that the changes to District 1 were necessary to comply with the Voting Rights Act of 1965 and that race had not played a predominant role in the selection of voters for District 12. A three-judge district court rejected both of those defenses. Led by Justice Kagan, the Supreme Court affirmed.

With respect to District 1, the evidence made it clear that those leading the redistricting effort wished to create a majority-minority district, and so the Court quickly turned its attention to whether there was a compelling justification for taking race predominantly into account. North Carolina argued that there was-namely, avoiding vote dilution in violation of the Voting Rights Act of 1965. In election after election in District 1 , however, numerous white voters had helped elect candidates favored by most blacks, and so the state did not have "good reasons" to fear that blacks' voting strength in that district was at risk of dilution. ${ }^{41}$ With respect to District 12-a storied district making its fifth appearance before the Court-
33. Id. at 1692 (internal quotation and citation omitted).

34. Id. at 1700-01.

35. Joined by Justice Alito, Justice Thomas concurred in the judgment. Because Morales-Santana could not obtain the relief he desired no matter how the Court ruled on his equal-protection claim, Justice Thomas found it unnecessary to reach the merits of that claim.

36. 137 S. Ct. 788 (2017).
37. Id. at 799 .

38. Id.

39. Justice Thomas also took issue with the Court's handling of a twelfth legislative district, the details of which will be of interest to those specializing in such claims.

40. 137 S. Ct. 1455 (2017).

41. Id. at 1469-72. 
[T]he Court issued a 6-3 per curiam opinion summarily reversing a ruling by the Arkansas Supreme Court concerning samesex marriages and birth certificates. the state argued that partisanship, rather than race, had been the basis for drawing the district's lines, and that lawmakers had simply opted to pack that district with Democrats. Reviewing the district court's contrary factual findings only for clear error, the Court rejected the state's argument. The redistricting plan's lead architects had said at various points that they were focusing on race, for example, and one expert witness concluded that race, rather than partisanship, far better explained the state's choice of district lines.

Joined by Chief Justice Roberts and Justice Kennedy, Justice Alito concurred in the judgment in part and dissented in part. He agreed that North Carolina violated the Equal Protection Clause when redrawing District 1's boundaries, but accepted the state's party-focused explanation of its reasons for redrawing District 12. On behalf of the majority, Justice Kagan replied that Justice Alito had ignored the clear-error standard of review and that his opinion "tracks, top-to-bottom and point-forpoint, the testimony of . . the State's star witness at trial-so much so that the dissent could just have block-quoted that portion of the transcript and saved itself a fair bit of trouble." 42

North Carolina v. Covington 43 was another racial gerrymandering case from the Tar Heel State, this one featuring a district court's finding that state officials had unconstitutionally drawn twenty-eight legislative districts' boundaries along racial lines. In a separate order, the Court summarily affirmed the district court's ruling on the merits of the plaintiff's claims. ${ }^{44}$ In this per curiam ruling handed down the same day, however, the Court unanimously vacated the district court's remedial order. In addition to setting a deadline by which new legislative boundaries needed to be drawn, the district court had ordered that the two-year terms of certain legislators be cut in half, had ordered that special elections be held for specified legislative seats, and had partially suspended the North Carolina Constitution's requirement that a legislative candidate live for one year in a district before being elected to represent it. Without taking a position on whether those remedial measures were justified, the Court held that, before imposing those remedies, the district court needed to engage in a more thorough, casespecific analysis of the equitable considerations at stake.

\section{Same-Sex Marriage}

Two years ago, in one of its most widely noted rulings of the past half century, the Court ruled in Obergefell v. Hodges 45 that the Fourteenth Amendment-through a combination of equalprotection and substantive-due-process principles-grants same-sex couples the right to marry and to have their marriages recognized in all states. On the closing day of its most recent Term, the Court issued a 6-3 per curiam opinion summarily reversing a ruling by the Arkansas Supreme Court concerning same-sex marriages and birth certificates. When two women in separate same-sex marriages gave birth in Arkansas, the Arkansas Department of Public Health refused to list the nonbirth spouses as parents on the children's birth certificates. The Court ruled in Pavan v. Smith ${ }^{46}$ that this flatly violated Obergefell's declaration that states must provide same-sex couples with "the constellation of benefits that the States have linked to marriage." 47 Joined by Justices Thomas and Alito, Justice Gorsuch dissented, arguing that the case merited full briefing and argument, that Obergefell had not squarely addressed the constitutional propriety of birth-certificate regimes like Arkansas's, and that it was "very hard to see what [wa]s wrong with" the Arkansas Supreme Court's conclusion "that rational reasons exist for a biology based birth registration regime."48

\section{FAIR HOUSING ACT}

In Bank of America Corp. v. City of Miami, ${ }^{49}$ Miami officials claimed that Bank of America and Wells Fargo had discriminated against Latino and African-American home-loan borrowers in a variety of ways, and that this discrimination resulted in lower tax revenues and higher municipal expenses for the city. Could Miami bring an action against the two banks under the Fair Housing Act? The answer to that question turned on at least two things: whether the city's claims fell within the zone of interests that Congress intended to protect when enacting the FHA and whether the city's harms had been proximately caused by the banks' alleged FHA violations. The court answered the first of those two inquiries in the affirmative and remanded the second for further consideration. ${ }^{50}$

Writing for the Court, Justice Breyer reminded readers that, when bringing a federal statutory claim, a federal plaintiff must meet the standing requirements of Article III and must show that it possesses a cause of action under the statute. To meet the latter requirement, a plaintiff must show that its interests at least arguably "fall within the zone of interests protected by the law invoked." 51 The FHA broadly permits suit by "any person ... . who claims to have been injured by a discriminatory housing practice" or who "believes that [it] will be injured by a discriminatory housing practice that is about to occur." 52 By using such capacious language, Justice Breyer wrote, Congress extended the pool of potential FHA plaintiffs to the full limits of what Article III allows.

With respect to causation, the Court was less definitive. The
42. Id. at 1473 n.6.

43. 137 S. Ct. 1624 (2017).

44. North Carolina v. Covington, No. 16-649 (U.S. June 5, 2017).

45. 135 S. Ct. 2584 (2015).

46. 137 S. Ct. 2075 (2017).

47. Id. at 2076, 2078 (quoting Obergefell, 135 S. Ct. at 2590).

48. Id. at 2079 (Gorsuch, J., dissenting).
49. 137 S. Ct. 1296 (2017)

50. Joined by Justices Kennedy and Alito, Justice Thomas argued that the Court should have rejected the city's arguments on both fronts.

51. Id. at 1302 (quoting Lexmark International, Inc. v. Static Control Components, Inc., 134 S. Ct. 1377, 1388 (2014)).

52. 42 U.S.C. \& 3602(i). 
Eleventh Circuit had concluded that the city met the FHA's causation requirement by pleading injuries that were the foreseeable result of FHA violations. The Supreme Court found, however, that the FHA is more demanding:

In the context of the FHA, foreseeability alone does not ensure the close connection that proximate cause requires. The housing market is interconnected with economic and social life. A violation of the FHA may, therefore, be expected to cause ripples of harm to flow far beyond the defendant's misconduct. Nothing in the statute suggests that Congress intended to provide a remedy wherever those ripples travel. ${ }^{53}$

But beyond indicating that there needed to be some kind of "direct" connection between an alleged FHA violation and the plaintiff's harm, the court declined "to draw the precise boundaries of proximate cause under the FHA." 54 None of the courts of appeals had yet addressed that issue, and so the Court opted to give them the first shot at tackling it.

\section{FALSE CLAIMS ACT}

The False Claims Act's qui tam enforcement provision enables a private party (a "relator") to bring an FCA action on behalf of the federal government against an individual whom he or she believes has "knowingly present[ed to the government] . . . a false or fraudulent claim for payment or approval." 55 The FCA further states that " $[\mathrm{t}]$ he complaint shall be filed in camera [and] shall remain under seal for at least 60 days." 56 In State Farm Fire E Casualty Co. v. United States ex rel. Rigsby57 - a case concerning allegations that, in the wake of Hurricane Katrina, State Farm fraudulently tried to shift some of its wind-insurance liabilities to the federal government-the Supreme Court was asked to determine whether a violation of the FCA's seal requirement mandates dismissal of a relator's complaint. In an opinion by Justice Kagan, the Court unanimously found that dismissal is not required, but rather is among the remedies that a district court may deem appropriate in its discretion.

\section{FAMILY LAW AND VETERANS' BENEFITS}

Howell v. Howell 58 concerned an issue that looms large when dealing with the distribution of veterans' benefits between divorcing spouses. When John and Sandra Howell divorced in 1991, the divorce decree declared that Sandra would receive half of John's Air Force retirement pay. That arrangement was permissible under the Uniformed Services Former Spouses'
Protection Act, which declares that states may treat veterans' "disposable retired pay" as community property divisible between divorcing spouses. 59 More than a decade later, the Department of Veterans Affairs determined that John suffered from a partial disability resulting from his military service, entitling him to disability benefits. Under federal law, however,

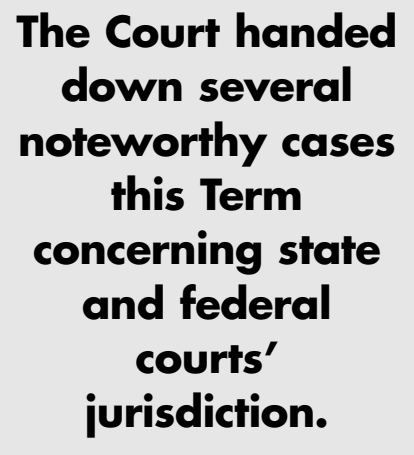
John could receive those disability benefits only if he agreed to take a corresponding reduction in the retirement pay that he and Sandra had been dividing. ${ }^{60}$ John agreed to that arrangement, surely appreciating the fact that, unlike veterans' ordinary retirement pay, veterans' disability benefits are statutorily exempt from federal, state, and local taxation. ${ }^{61}$ Of course, by making that choice, he reduced the amount of his monthly retirement pay that Sandra received each month. Unhappy with the cut in her monthly payments, Sandra asked an Arizona family court to order John to make up the difference. The family court agreed to do so and the Arizona Supreme Court affirmed.

Led by Justice Breyer, the U.S. Supreme Court reversed. As the Court explained in 1989's Mansell v. Mansell,62 Congress has declared that states cannot treat as divisible community property any amount of retirement pay that a veteran has waived to receive disability benefits. ${ }^{63}$ (Congress has thereby ensured that the financial benefits of disability payments go entirely to the veteran himself or herself.) By ordering John to make up for the reduction that his waiver had yielded in Sandra's share of the retirement pay, Justice Breyer explained, Arizona's courts tried to do what Congress has explicitly forbidden. Justice Breyer closed by "not[ing] that a family court, when it first determines the value of a family's assets, remains free to take account of the contingency that some military retirement pay might be waived, or . . . take account of reductions in value when it calculates or recalculates the need for spousal support." 64

\section{JURISDICTION}

The Court handed down several noteworthy cases this Term concerning state and federal courts' jurisdiction. In BNSF Railway Co. v. Tyrrell, 65 the Court held (over the lone dissent of Justice Sotomayor) that the Montana Supreme Court erred when it determined that the courts of that state could exercise personal jurisdiction over BNSF Railway Company. ${ }^{66}$ The issue
53. Bank of America, 137 S. Ct. at 1306 (citation and internal quotation omitted).

54. Id.

55. 31 U.S.C. § 3729 (a)(1)(A); see also 31 U.S.C. 3730(b)(1) (presenting the qui tam provision).

56. 31 U.S.C. $\S 3730($ b)(2).

57. 137 S. Ct. 436 (2016).

58. 137 S. Ct. 1400 (2017).

59. 10 U.S.C. $\& 1408(c)(1)$.

60. 38 U.S.C. $\S 5305$.
61. 38 U.S.C. $\$ 5301(a)(1)$

62. 490 U.S. $581,588-95$ (1989).

63. 10 U.S.C. \& 1408(a)(4)(A)(ii).

64. Howell, 137 S. Ct. at 1406.

65. 137 S. Ct. 1549 (2017).

66. The Court also held that 45 U.S.C. § 56-a provision of the Federal Employers' Liability Act—does not address personal jurisdiction over railroads. Instead, that provision addresses issues of federal venue and concurrent federal-state jurisdiction. 


Writing for the
Court, Justice Alito
explained that
California's
"sliding-scale"
framework was
nothing more than
"a loose and
spurious form
of general
jurisdiction."

arose when two former BNSF employees sued the company in a Montana state court for injuries they allegedly suffered while on the job. Because the employees' claims did not flow from actions occurring in Montana, the inquiry focused on general, rather than specific, jurisdiction. Relying particularly upon its 2014 ruling in Daimler AG v. Bauman, ${ }^{67}$ Justice Ginsburg explained for the Court that a state court may take general jurisdiction over a corporation without fear of violating the Fourteenth Amendment's Due Process Clause only when the corporation is incorporated in that state, when its principal place of business is in that state, or when "exceptional" circumstances indicate that the corporation's activities in that state are "so substantial and of such a nature as to render the corporation at home in that State.""68 BNSF did own more than 2,000 miles of track in Montana and did employ more than 2,000 employees there. But when considered against the backdrop of BNSF's entire operations, those facts were not sufficient to establish that BNSF was "essentially at home" in Montana. ${ }^{69}$ BNSF's contacts with Montana would suffice to establish specific personal jurisdiction in a case concerning BNSF's activities in Montana, but they were not enough to create general personal jurisdiction there.

The focus shifted to specific jurisdiction in Bristol-Myers Squibb Co. v. Superior Court of California. ${ }^{70}$ In that case, nearly 680 individuals filed actions against Bristol-Myers Squibb in California for injuries they allegedly suffered from taking the defendant's Plavix, a blood-thinning drug. Eighty-six of those plaintiffs resided in California, and, as to them, there was no jurisdictional question. The remainder of the plaintiffs, however, came from 33 other states. Did the Fourteenth Amendment's Due Process Clause permit California's courts to take specific jurisdiction of the non-Californians' claims? The California Supreme Court concluded that it did, reasoning that a "sliding-scale approach" was appropriate: the greater the number of contacts between a defendant and a forum state, the looser may be the connection between the defendant's activities in the forum and the plaintiffs' claims. Here, although Bristol-Myers did not design, manufacture, package, or label Plavix in California, it did have numerous other contacts with the state, and the non-Californians' claims were similar to those filed by the California residents. For the California Supreme Court, there thus was a sufficient, jurisdiction-establishing connection between California and the activities giving rise to the non-Californians' claims.

Over the lone dissent of Justice Sotomayor (just as in BNSF Railway), the Supreme Court rejected the California Supreme Court's framework and conclusion. Writing for the Court, Justice Alito explained that California's "sliding-scale" framework was nothing more than "a loose and spurious form of general jurisdiction." 71 The decisive factor cutting against jurisdiction here was the fact that there simply was no connection between California and the activities giving rise to the non-Californians' claims. Those plaintiffs had not purchased, taken, or been injured by Plavix in California, and the fact that their claims were similar to claims filed by Californians was irrelevant. The Court "le[ft] open the question whether the Fifth Amendment imposes the same restrictions on the exercise of personal jurisdiction by a federal court." 72 Writing in dissent, Justice Sotomayor argued that "there is nothing unfair about subjecting a massive corporation to suit in a State for a nationwide course of conduct that injures both forum residents and nonresidents alike," 73 and she warned that the majority's ruling would have justice-thwarting consequences in cases in which a defendant has injured plaintiffs in numerous states.

In Town of Chester v. Laroe Estates, Inc. ${ }^{74}$ the Court turned its attention to issues of standing and intervention of right under Federal Rule of Civil Procedure 24(a). Must a party seeking to intervene under that rule independently meet Article III's familiar standing requirements of injury, causation, and redressability if the existence of an Article III "case" or "controversy" has already been established in the underlying litigation? Laroe Estates had sought to intervene in litigation concerning a realestate development project that went south allegedly as a result of unlawful actions by municipal officials in Chester, New York. Like the original plaintiff, Laroe wished to assert a regulatory takings claim against the town. The Second Circuit held that, because the original plaintiff had standing under Article III, Laroe did not itself need to satisfy Article III's requirements.

Resolving a circuit split on the relationship between Article III and Rule 24(a), the justices vacated the Second Circuit's judgment. Writing for the unanimous Court, Justice Alito began by reminding readers that, when a plaintiff brings an action against a defendant in federal court, it must establish Article III standing for each of its claims and for each form of relief that it seeks. The same principle holds, Justice Alito explained, when a case features multiple plaintiffs: "[a]t least one plaintiff must have standing to seek each form of relief requested in the complaint." 75 The Court held that the same logic applies when a party seeks to intervene under Rule 24(a): "[A]n intervenor of right must have Article III standing in order to pursue relief that is different from that which is sought by a party with standing." 76 Laroe thus would need to meet
67. 134 S. Ct. 746 (2014).

68. BNSF Railway Co., 137 S. Ct. at 1558 (quoting Daimler, 134 S. Ct. at $761, n .19)$.

69. Id. at 1559 (quoting Daimler, 134 S. Ct. at 754, which in turn was quoting Goodyear Dunlop Tires Operations, S.A. v. Brown, 564 U.S. 915,919 (2011)).

70. 137 S. Ct. 1773 (2017).
71. Id. at 1781 .

72. Id. at $1783-84$.

73. Id. at 1784 (Sotomayor, J., dissenting).

74. 137 S. Ct. 1645 (2017).

75. Id. at 1651 .

76. Id. 
Article III's requirements if it was seeking "a money judgment of its own running directly against the Town." 77 The Court remanded for a determination of whether that was, indeed, the form of relief that Laroe sought.

In Lightfoot v. Cendant Mortgage Corp. ${ }^{78}$ the Court considered whether a statutory sue-and-be-sued clause regarding the Federal National Mortgage Association (Fannie May) gives federal district courts subject-matter jurisdiction to hear all claims concerning Fannie May, or whether it merely gives Fannie May the capacity to file lawsuits and to be sued by others. The statutory language at issue authorizes Fannie May "to sue and to be sued, and to complain and to defend, in any court of competent jurisdiction, State or Federal."79 Resolving a circuit split, the Court unanimously determined that the statute does not provide an independent source of federal jurisdiction. The Court's analysis turned primarily upon the statute's use of the phrase "any court of competent jurisdiction." By virtue of that language, Justice Sotomayor explained, the statute merely "permits suit in any state or federal court already endowed with subject-matter jurisdiction over the suit." 80

Suppose federal plaintiffs file claims on their own behalf against a defendant, as well as claims on behalf of a class they propose to represent. Suppose, further, that the district court refuses to certify the class, after which the plaintiffs voluntarily agree to the dismissal of their individual claims with prejudice but then appeal the denial of class certification. Does the federal appellate court have jurisdiction? That was the question before the Court in Microsoft Corp. v. Baker, 81 in which owners of Microsoft's Xbox game console filed design-defect claims on behalf of themselves and a proposed class of Xbox owners. After the district court struck their class allegationsthe functional equivalent of denying a motion for class certification-the plaintiffs appealed the district court's ruling on the class claims, arguing that the Ninth Circuit should take jurisdiction under Rule 23(f) of the Federal Rules of Civil Procedure. That rule gives federal appellate courts the discretionary power to take jurisdiction of orders granting or denying class certification-interlocutory orders that ordinarily would otherwise be appealable only under the stringent circumstances described in 28 U.S.C. $\S 1292$ (b). The Ninth Circuit refused to take the case, but the plaintiffs were undeterred. In an effort to render the case appealable as of right under 28 U.S.C. \& 1291the familiar statute that gives courts of appeals jurisdiction to review district courts' "final decisions"-the plaintiffs then stipulated to the dismissal of their individual claims with prejudice and appealed the district court's ruling striking their class allegations. The Ninth Circuit determined that Section 1291 did indeed give it jurisdiction to hear the plaintiffs' appeal. The court then ruled that the district court abused its discretion when it struck the plaintiffs' class allegations.

All eight of the Court's participating justices rejected the Ninth Circuit's finding that it had jurisdiction, though they disagreed about the nature of the error. Writing for the fivemember majority, Justice Ginsburg determined that the Ninth Circuit lacked jurisdiction because the district court's ruling dismissing the plaintiffs' individual claims was not a "final decision" within the meaning of Section 1291. To rule otherwise, Justice Ginsburg reasoned, would allow plaintiffs to manufacture finality in the face of what is otherwise plainly an interlocutory ruling on class certification, and would disrupt the balance of interests struck in Rule 23(f). Concurring in the judgment and joined by Chief Justice Roberts and Justice Alito, Justice Thomas concluded that the district court's dismissal of the plaintiffs' individual claims was an appealable "final decision[]" within the meaning of Section 1291, because that ruling left the district court with no further work to do. ${ }^{82}$ Justice Thomas nevertheless found that the plaintiffs' appeal failed to satisfy the caseor-controversy requirements imposed by Article III. "[I]t has long been the rule," he wrote, "that a party may not appeal from the voluntary dismissal of a claim, since the party consented to the judgment against it." 83

\section{PATENTS}

It was a busy Term for the Court in the area of patents, and a correspondingly unhappy Term for the Federal Circuit, which suffered reversals in six of its seven cases reviewed by the Court. ${ }^{84}$ We will take a short look at three of those reversals. Perhaps the most important of them came in Impression Products, Inc. v. Lexmark International, Inc., ${ }^{85}$ a case asking whether a patent holder can use patent law to control the downstream use of a product after the patent holder sells it. Lexmark owns various patents for toner cartridges that it manufactures and sells. It sells those cartridges at a discount if the purchaser contractually agrees to return the empty cartridges to Lexmark, rather than transferring them to another company in the business of refilling and selling cartridges. Many Lexmark cartridges sold under those terms nevertheless found their way into the hands of Impression Products, a company that refills and sells other companies' used toner cartridges. Lexmark sued Impression Products for patent infringement, arguing that, "because it expressly prohibited reuse and resale of those cartridges, [Impression Products and other companies
77. Id. at 1652 .

78. 137 S. Ct. 553 (2017).

79. 12 U.S.C. \& $1723 a(a)$.

80. Lightfoot, 137 S. Ct. at 561.

81. 137 S. Ct. 1702 (2017).

82. Id. at 1716 (Thomas, J., concurring in the judgment). The major83. Id. ity did not directly respond to this seemingly powerful point.
84. See Bhatia, supra note 1 , at 3.

85. 137 S. Ct. 1523 (2017). For contemporaneous commentary on the case and its significance, see Ronald Mann, Opinion Analysis: Federal Circuit Loses Again, as Justices Categorically Reject Enforcement of Post-Sale Patent Restrictions, SCOTUSblog (May 30, 2017, 4:35 PM), http://www.scotusblog.com/2017/05/opinion-analysisfederal-circuit-loses-justices-categorically-reject-enforcementpost-sale-patent-restrictions/\#more-256236. 


[T]he Court held
in Trinity
Lutheran Church
of Columbia, Inc.
v. Comer that
Missouri could
not categorically
exclude a church-
run daycare from
competing for a
state grant to
resurface its
playground.

in the same line of work] infringed the Lexmark patents when they refurbished and resold them." 86 The Federal Circuit held that Lexmark could sue Impression Products for patent infringement, but the Supreme Court reversed. Writing for the Court, Chief Justice Roberts explained that, while Lexmark might have a breach-of-contract action when a customer disregards its promise to return an empty cartridge to Lexmark, Lexmark fully exhausts its patent rights at the moment of sale. "A patentee is free to set the price and negotiate contracts with purchasers," Chief Justice

Roberts wrote, "but may not, 'by virtue of his patent, control the use or disposition' of the product after ownership passes to the purchaser." 87 The Court further held that the patentexhaustion rule applies to goods sold domestically and internationally alike.

In Samsung Electronics Co., Ltd. v. Apple Inc., 88 the Court was asked to settle a disagreement about the meaning of Section 289 of the Patent Act, which imposes liability upon any person who "sells or exposes for sale any article of manufacture to which [a patented] design or colorable imitation has been applied." 89 The Court unanimously held that, when dealing with a multicomponent product, the phrase "article of manufacture" can refer either to the entire product or to a single component of it. The Federal Circuit had thus erred when it concluded that, as a remedy for Samsung's infringement of some of Apple's design patents for the iPhone, Apple was necessarily entitled to all of the profits Samsung had made from sales of its infringing smartphones (rather than just to the profits Samsung had made from sales of the infringing components themselves). The Court left it to the Federal Circuit, on remand, to determine "whether, for each of the design patents at issue here, the relevant article of manufacture is the smartphone, or a particular smartphone component." 90 Appearing as an amicus, the United States had proposed a test for making that determination, but the Court preferred not to make any decision about the appropriate test in the absence of full briefing on the issue.

The Federal Circuit suffered another reversal in Life Technologies Corp. v. Promega Corp. ${ }^{91}$ That case concerned Section 271(f)(1) of the Patent Act, which imposes patent-infringement liability upon anyone who, from within the United
States, supplies "all or a substantial portion of the components of a patented invention" for combination outside the United States. ${ }^{92}$ Life Technologies had shipped one component of a five-component invention from the United States to the United Kingdom, where the components were combined to make the final patented product. Focusing on the statutory phrase "all or a substantial portion," the Federal Circuit had held that the component supplied from within the United States was an especially important piece of the patented puzzle, that the component was thus a "substantial" piece of the puzzle, and that Life Technologies had thus violated Section 271(f)(1). The Supreme Court reversed, finding that the meaning of the term "substantial" in this context is quantitative, rather than qualitative, in nature, and that the statute "does not cover the supply of a single component of a multicomponent invention."93

\section{RELIGION}

In one of its most widely anticipated rulings of the Term, the Court held in Trinity Lutheran Church of Columbia, Inc. v. Comer $^{94}$ that Missouri could not categorically exclude a church-run daycare from competing for a state grant to resurface its playground. Through Missouri's Scrap Tire Program, the state offered a limited number of grants to help organizations resurface their playgrounds with material made from recycled tires. In an effort to comply with its strong constitutional commitment to the separation of church and state, however, Missouri disqualified all churches and other religious organizations-including the Trinity Lutheran Church and its daycare-from competing for one of the grants. Defending that disqualification, the state relied heavily upon the Court's 2004 ruling in Locke v. Davey, 95 in which the Court ruled that the State of Washington could refuse to provide scholarship funds to a student pursuing a degree in devotional theology.

In an opinion authored by Chief Justice Roberts, the Court ruled that Missouri's categorical exclusion violated Trinity Lutheran's rights under the First Amendment's Free Exercise Clause. In Locke, Chief Justice Roberts explained, the student "was not denied a scholarship because of who he was; he was denied a scholarship because of what he proposed to do-use the funds to prepare for the ministry."96 Trinity Lutheran, however, had been denied the opportunity to compete for a grant "because of what it is-a church." 97 In this important respect, the Court found, Trinity Lutheran had suffered the same status-based injury that had been declared unconstitutional in 1978's McDaniel v. Paty. ${ }^{98}$ In that case, the Court struck down a Tennessee law that categorically barred ministers from serving as delegates to the state's constitutional convention.

In a footnote about which we undoubtedly will hear more in the future, Chief Justice Roberts stated that " $[\mathrm{t}]$ his case involves express discrimination based on religious identity
86. Impression Products, 137 S. Ct. at 1530.

87. Id. at 1531 (quoting United States v. Univis Lens Co., 316 U.S. 241, 250 (1942) (emphasis omitted)).

88. 137 S. Ct. 429 (2016).

89. 35 U.S.C. § 289.

90. Samsung Electronics Co., 137 S. Ct. at 436.

91. 137 S. Ct. 734 (2017).
92. 35 U.S.C. \& 271(f)(1).

93. Life Technologies, 137 S. Ct. at 743.

94. 137 S. Ct. 2012.

95. 540 U.S. 712 (2004).

96. Trinity Lutheran, 137 S. Ct. at 2023.

97. Id.

98. 435 U.S. 618 (1978). 
with respect to playground resurfacing," and that the Court was not "address[ing] religious uses of funding or other forms of discrimination."99 Joined by Justice Thomas, Justice Gorsuch refused to join that footnote (thereby reducing it to the status of a plurality opinion), because it could provide a basis for greatly restricting the precedential reach of the Court's opinion. Joined by Justice Gorsuch, Justice Thomas wrote separately to express dissatisfaction with the Court's prior ruling in Locke-dissatisfaction that animated portions of Justice Gorsuch's separate opinion, as well.

Justice Breyer concurred in the judgment, arguing that, just as the Free Exercise Clause would not permit a state to deny policy and fire protection to a church, so too it bars a state from excluding churches "from participation in a general program designed to secure or to improve the health and safety of children." 100 Justice Ginsburg joined Justice Sotomayor in dissent, arguing that the Establishment Clause does not permit Missouri to provide direct funding to Trinity Lutheran (just as it would not permit the state to pay for repairs to the church's walls or pews), and that the Court's ruling on the Free Exercise Clause was faithful neither to Locke nor to much of the nation's legal history.

\section{SOVEREIGN IMMUNITY}

The Court resolved two issues in memorably named Lewis $v$. Clarke, ${ }^{101}$ one concerning the scope of tribal sovereign immunity and the other concerning the doctrine of sovereign immunity more generally. The issues arose from a simple set of allegations. Brian and Michelle Lewis claimed that, while driving on Interstate 95 in Connecticut, they were rear-ended by William Clarke, an employee of the Mohegan Tribal Gaming Authority who was driving customers of the Mohegan Sun Casino to their homes. When the Lewises sued Clarke in his individual capacity in a Connecticut state court, Clarke argued he was protected by tribal sovereign immunity. He offered two rationales for invoking that defense: he was acting within the scope of his tribal duties at the time of the accident, and the Mohegan Tribe had statutorily agreed to indemnify tribal gaming employees for losses they suffered as a result of their negligent on-the-job conduct. The Connecticut Supreme Court embraced the first rationale, but the U.S. Supreme Court rejected both.

Writing for the Court, 102 Justice Sotomayor first determined that there was no reason to extend the sovereign-immunity defense to tribal employees under circumstances in which the defense would not extend to state and federal employees. Under well-settled principles, Justice Sotomayor explained, the availability of sovereign immunity as a defense turns in large part on whether a governmental employee has been sued in his or her official or individual capacity. Suits against employees in their official capacities are really suits against their sovereign employers, and so sovereign immunity in in play. When an employee has been sued in his or her personal capacity, however, it is the employee-and not the employer-that is the real party in interest.

Justice Sotomayor next observed that this case presented the Court with its first opportunity "to decide whether an indemnification clause is sufficient to extend a sovereign immunity defense to a suit against an employee in his individual capacity." 103 The Court
Those awaiting a major ruling concerning the intersection of the Internet and the First Amendment's Speech Clause got at least part of what they wanted in Packingham v. North Carolina. made short work of that question, answering it in the negative. "The critical inquiry," Justice Sotomayor wrote, "is who may be legally bound by the court's adverse judgment, not who will ultimately pick up the tab." 104 In an individual-capacity lawsuit, a court's judgment binds the employee, not the sovereign employer-and that remains true even when the sovereign has volunteered to make its employees whole for losses they suffer as a result of negligently carrying out their job duties.

\section{SPEECH}

Those awaiting a major ruling concerning the intersection of the Internet and the First Amendment's Speech Clause got at least part of what they wanted in Packingham v. North Carolina. ${ }^{105}$ Lester Packingham had posted a statement on Facebook, thanking God that a court dismissed his traffic ticket. The problem? As a convicted sex offender, Packingham was barred by North Carolina law from accessing social networking sites like Facebook, Twitter, and LinkedIn (and possibly also sites like Amazon, Washingtonpost.com, and WebMD). In an opinion joined by the Court's Democratic appointees, Justice Kennedy observed that cyberspace had joined streets and parks as a key place where Americans routinely go to inquire, speak, listen, learn, and protest. Turning to the intermediate scrutiny appropriate for content-neutral speech regulations, the Court found that the law burdened substantially more speech than was necessary to achieve its goal of protecting children from sexual abuse. The statute's prohibition was "unprecedented in the scope of First Amendment speech it burdens," Justice Kennedy wrote, and "no case or holding of this Court has approved of a statute as broad in its reach." 106

Joined by Chief Justice Roberts and Justice Thomas, Justice Alito concurred in the judgment. Because North Carolina's law "precludes access to a large number of websites that are most unlikely to facilitate the commission of a sex crime against a child," 107 Justice Alito agreed that the statute burdened sub-
99. Trinity Lutheran, 137 S. Ct. at 2024 n.3.

100. Id. at 2027 (Breyer, J., concurring in the judgment).

101. 137 S. Ct. 1285 (2017).

102. Justices Ginsburg and Thomas separately concurred in the judgment.
103. Id. at 1293.

104. Id. at 1293-94.

105. 137 S. Ct. 1730 (2017).

106. Id. at 1737 .

107. Id. at 1741 (Alito, J., concurring in the judgment). 


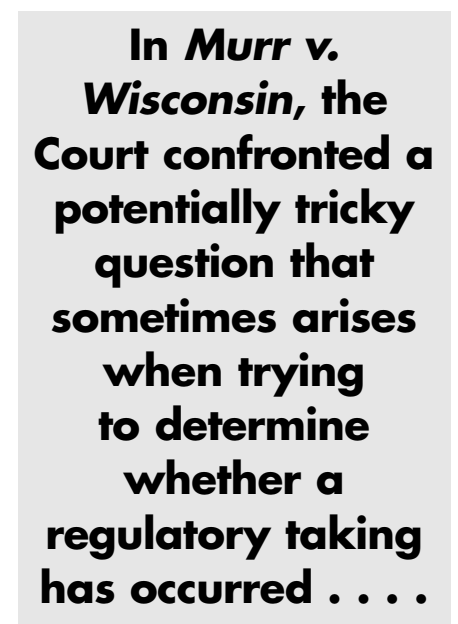

stantially more speech than necessary. He declined to join the majority's opinion, however, because Justice Kennedy had appeared to equate the Internet with streets and parks. There are differences between the Internet and physical spaces, Justice Alito observed: parents can monitor their children's physical locations and in-person contacts more easily than they can monitor their kids' Internet traffic, for example, and criminals can cloak themselves in anonymity more easily online than they can in person. For Justice Alito, those differences suggested that the Court should proceed cautiously before appearing to indicate that the First Amendment restricts states' ability to regulate speech on the Internet just as vigorously as it restricts their ability to regulate speech in traditional public forums. Justice Kennedy agreed that caution was appropriate, but for him that caution ran largely in the opposite direction: he worried that the Court would be too slow to acknowledge all of the speech-facilitating implications of the Internet revolution.

Packingham was not the Court's only noteworthy decision concerning the freedom of speech this year. In its sole affirmance of the Federal Circuit this Term, the Court agreed with that court's finding that a federal statute strayed into unconstitutional territory when it authorized the government to withhold a trademark on the ground that it may "disparage . . persons, living or dead, institutions, beliefs, or national symbols, or bring them into contempt, or disrepute."108 In Matal $v$. Tam, 109 the Patent and Trademark Office had relied upon that statute when refusing to register "The Slants" as an Asian band's trademark. The Federal Circuit found the statutory provision facially unconstitutional, and-led in part by Justice Alito-the Supreme Court agreed. In a portion of the opinion joined by all eight of the participating justices, Justice Alito began by eviscerating the government's suggestion that registered trademarks are government speech and thus beyond the reach of First Amendment limitations. In a passage attracting only a plurality, Justice Alito then found that, even if the case was governed by the somewhat more relaxed scrutiny appropriate for regulations of commercial speech-a question the plurality found unnecessary to resolve-the statutory language here was plainly unconstitutional. The First Amendment does not permit the government to restrict speech merely on the ground that it will offend or demean people on the basis of their race, ethnicity, sex, or other trait. Joined by Justices Ginsburg, Sotomayor, and Kagan, Justice Kennedy concurred in part and concurred in the judgment, finding that the statute impermissibly discriminated based upon viewpoint.

\section{TAKINGS}

In Murr v. Wisconsin, ${ }^{110}$ the Court confronted a potentially tricky question that sometimes arises when trying to determine whether a regulatory taking has occurred: When evaluating the extent to which government regulation has reduced the value of an owner's property, what is the unit of property on which that analysis should focus? The facts in Murr illustrate the problem. In successive years, siblings in the Murr family together acquired two adjacent parcels of land in Wisconsin. To help pay for improvements on one of the lots, the siblings wished to sell the other. A Wisconsin regulation stated, however, that when adjacent lots were held under common ownership, none of the lots could be separately sold or developed unless it contained at least one acre of land suitable for development. The lot that the siblings wished to sell did not meet that requirement. Did the restriction amount to a compensable taking under the Fifth Amendment? The answer to that question depended largely on how one defined the property at issue: should a court look at the diminution in value of the single lot that the Murrs could not sell (in which case there likely would be a taking), or should a court look instead at the diminution in value of the two lots taken together?

Writing for the majority, and emphasizing that "[a] central dynamic of the Court's regulatory takings jurisprudence . . . is its flexibility,"111 Justice Kennedy concluded that what ultimately mattered was the regulation's impact on the value of the two lots taken together. In reaching that conclusion, the majority did not narrowly focus_-as Chief Justice Roberts and Justices Thomas and Alito, in dissent, would have had it-on whether Wisconsin law continued to define the two lots as separate parcels of land. Rather, Justice Kennedy concluded that a court should examine numerous factors:

These include the treatment of the land under state and local law; the physical characteristics of the land; and the prospective value of the regulated land. The endeavor should determine whether reasonable expectations about property ownership would lead a landowner to anticipate that his holdings would be treated as one parcel, or, instead, as separate tracts. The inquiry is objective, and the reasonable expectations at issue derive from background customs and the whole of the legal tradition. ${ }^{112}$

After examining each of those factors, the Court concluded that it should treat the Murr siblings' two lots as a single parcel of land, and that no compensable taking had occurred.

\section{THE TRUMP ADMINISTRATION'S "TRAVEL BAN"}

Laying the groundwork for what will likely be one of its most significant rulings next Term, the Court in Trump v. International Refugee Assistance Project ${ }^{113}$ agreed to review lower courts' decisions temporarily enjoining enforcement of the Trump Administration's "travel ban." The executive order 
being challenged seeks to limit the flow of refugees into the United States and (with case-by-case exceptions) seeks temporarily to bar the entry of nationals from Iran, Libya, Somalia, Sudan, Syria, and Yemen. Oral arguments on those matters are slated to be heard early in the Court's October 2017 Term.

Pending its review, the Court partially granted the Government's request to stay enforcement of the lower courts' injunctions. Until the Court says otherwise, the injunctions remain in place only for those who possess a "bona fide relationship with a person or entity in the United States." 114 That is, the injunctions are effective only for those who have either "a close familial relationship" with a person in the United States or a formal, documented relationship with an entity in the United States (such as a student's relationship with a university, a worker's relationship with an employer, or a lecturer's relationship with an audience). Joined by Justices Alito and Gorsuch, Justice Thomas concurred in part and dissented in part, arguing that the Court should have stayed the enforcement of the injunctions in their entirety.

\section{OTHER NOTABLE RULINGS}

In McLane Co., Inc. v. Equal Employment Opportunity Commission, ${ }^{115}$ the Court determined that "a court of appeals should review a district court's decision to enforce or quash an EEOC subpoena" for abuse of discretion, rather than de novo. 116

In Star Athletica, L.L.C. v. Varsity Brands, Inc.117-a case featuring a copyright dispute between two makers of cheerleader uniforms-the Court held that "a feature of the design of a useful article is eligible for copyright if, when identified and imagined apart from the useful article [as with the decorations on the uniforms at issue here], it would qualify as a pictorial, graphic, or sculptural work either on its own or when fixed in some other tangible medium." 118

Resolving a circuit split and a disagreement among the members of the Texas Court of Appeals, the Court determined in Water Splash, Inc. v. Menon 119 that the Convention on the Service Abroad of Judicial and Extrajudicial Documents in Civil and Commercial Matters (also known as the Hague Service Convention) does not forbid the international service of process by mail.

In Kokesh v. SEC, 120 the Court resolved another circuit split by unanimously holding that, when the Securities and Exchange Commission orders disgorgement in an enforcement proceeding, it is imposing a "penalty" within the meaning of 28 U.S.C. \& 2462, and any such action for disgorgement thus must be brought within the five-year period established by that statutory provision. In a footnote, the Court cautioned readers that it was not stating "an opinion on whether courts possess authority to order disgorgement in SEC enforcement proceedings," but was instead only addressing the reach of Section 2462's limitations period. ${ }^{121}$

In another securities case-California Public Employees' Retirement System v. ANZ Securities, Inc.122 - the Court ruled that the three-year time bar established by Section 13 of the Securities Act of 1933 is a statute of repose, rather than a statute of limitations, and thus is not subject to equitable tolling on behalf of investors who opt out of a timely filed putative class action but fail to file their own complaints the time bar.

\section{LOOKING AHEAD}

At the time of this writing, several politically charged cases are looming especially large for the Court's October 2017 Term: Trump v. International Refugee Assistance Project ${ }^{123}$ and Trump v. Hawaii, ${ }^{124}$ on the Trump Administration's "travel ban"; Gill v. Whitford, ${ }^{125}$ on partisan gerrymandering; and Masterpiece Cakeshop, Ltd. v. Colorado Civil Rights Commission, ${ }^{126}$ on the scope of a baker's religious freedom to refuse to make wedding cakes for same-sex couples. There will, of course, be a host of others, on issues ranging from whether Iranian property on loan to the University of Chicago can be seized to satisfy a judgment against Iran arising out of a 1997 bombing in Jerusalem, ${ }^{127}$ to whether Congress may bar the states from repealing their bans on sports gambling. ${ }^{128}$

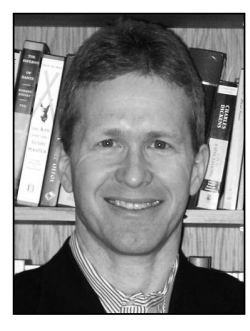

Professor Todd E. Pettys holds the H. Blair and Joan V. White Chair in Civil Litigation at the University of Iowa College of Law. He regularly teaches courses on constitutional law, as well as a Supreme Court seminar, and he is the author of a forthcoming Oxford University Press book on the Iowa Constitution. He joined the Iowa faculty in 1999.
114. Id. at 2008.

115. 137 S. Ct. 1159 (2017).

116. Id. at 1164 .

117. 137 S. Ct. 1002 (2017).

118. Id. at 1012.

119. 137 S. Ct. 1504 (2017).

120. 137 S. Ct. 1635 (2017).

121. Id. at 1642 n.3.
122. 137 S. Ct. 2042 (2017).

123. No. 16-1436.

124. No. 16-1540.

125. No. 16-1161.

126. No. 16-111.

127. Rubin v. Islamic Republic of Iran, No. 16-534.

128. Christie v. NCAA, No. 16-476; New Jersey Thoroughbred Horsemen's Association, Inc. v. NCAA, No. 16-477. 